\title{
ECONOMIC VIABILITY OF FOUR CHARCOAL PRODUCTIVE SYSTEMS FROM MINAS GERAIS STATE
}

\author{
Gabriel Browne de Deus Ribeiro $2^{*} \odot$, Angélica de Cássia Oliveira Carneiro ${ }^{3} \odot$, Artur Queiroz Lana ${ }^{4} \odot$ and $^{\circ}$ \\ Sebastião Renato Valverde ${ }^{3}$ (웅
}

\footnotetext{
${ }^{1}$ Received on 11.04.2019 accepted for publication on 18.09.2019.

${ }^{2}$ Universidade Federal de Viçosa, Programa de Pós-Graduação em Ciência Florestal, Viçosa , MG - Brasil. E-mail: <gabrielbrowne@ gmail.com>.

${ }^{3}$ Universidade Federal de Viçosa, Departamento de Engenharia Florestal, Viçosa , MG - Brasil. E-mail: <cassiacarneiro1@gmail.com> and <valverde@ufv.br>.

${ }^{4}$ Universidade de São Paulo, Programa de Pós-Graduação em Recursos Florestais, Butanta, SP - Brasil. E-mail: <arturqlana@yahoo.com. br>.

*Corresponding author.
}

\begin{abstract}
This work analyzed the economic viability of four charcoal productive systems from Minas Gerais state, namely: fornos-fornalha, rabo-quente, encosta and superficie. The evaluated systems have an estimated productive capacity of about 100 cubic meters of charcoal per month. Implementation and maintenance expenses and productive parameters were obtained in the literature and from local producers of Lamim (MG), a productive center in the state, during the year of 2018. Silvicultural costs were not considered, only the wood purchase. For the economic evaluation, Net Present Value (NPV), Modified Internal Rate of Return (MIRR), Payback, capex and opex were analyzed, and it was also evaluated the systems' economic sensitivity to charcoal price and gravimetric yield variations. The main results showed that all the systems were economically viable by NPV criteria; only rabo-quente system was not viable by MIRR criteria; fornos-fornalha system presented the best economic results, greater capacity of net revenues and free cash flow generation, and lower operational expenses. This productive system was also less sensitive to charcoal price fluctuations and to its charcoal yield reduction. Given this fact, its insertion may be attractive in the productive reality of small and medium producers. In addition, the possibility of selling charcoal fines resulted in improvements in economic indicators, especially for traditional production systems: rabo-quente and encosta.
\end{abstract}

Keywords: Biomass energy; Gravimetric yield; Economic analysis.

\section{VIABILIDADE ECONÔMICADEQUATROSISTEMASPRODUTIVOS DE CARVÃO VEGETAL DO ESTADO DE MINAS GERAIS}

RESUMO - Este trabalho analisou a viabilidade econômica de quatro sistemas produtivos de carvão vegetal no estado de Minas Gerais, sendo eles: fornos-fornalha, rabo-quente, encosta e superficie. Os sistemas avaliados foram estimados para uma capacidade produtiva aproximada de 100 metros cúbicos de carvão vegetal por mês. Os custos de implantação, manutenção e os parâmetros produtivos foram obtidos na literatura e junto a produtores locais de Lamim (MG), polo produtivo no estado, durante o ano de 2018. Não foram considerados os custos silviculturais, apenas o valor da compra de madeira. Para a avaliação econômica, foram analisados o Valor Presente Líquido (VPL), a Taxa Interna de Retorno Modificada (MTIR), o Payback, o capex e o opex, além de se avaliar a sensibilidade dos sistemas frente a flutuações de preço e rendimento do carvão vegetal. Os principais resultados demonstraram que todos os sistemas foram viáveis economicamente pelo critério do VPL; apenas o sistema rabo-quente não foi viável pelo critério da MTIR; o sistema fornos-fornalha apresentou os melhores resultados econômicos, com maior capacidade de geração de receita líquida e de fluxo de caixa livre, também apresentando o menor custo operacional. Este sistema produtivo ainda demonstrou menor sensibilidade com relação às flutuações do preço de venda do carvão vegetal e da redução de seu rendimento em carvão vegetal. Dado o fato, sua inserção pode ser um atrativo para a realidade produtiva de pequenos e médios produtores. Além disso, a possibilidade da venda da moinha de carvão resultou em melhorias nos indicadores econômicos, principalmente para os sistemas produtivos tradicionais: fornos rabo-quente e de encosta.

Palavras-Chave: Energia de biomassa; Rendimento gravimétrico; Análise econômica.

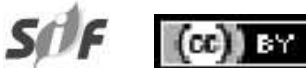

Revista Árvore 2020;44:e4401 http://dx.doi.org/10.1590/1806-908820200000001 


\section{INTRODUCTION}

Brazil is one of the world's largest charcoal producer and the only country that performs this activity on industrial scale, which is mainly destined for pig iron, steel and ferroalloys sectors (EPE, 2018). Currently the state of Minas Gerais is the greatest forest producer in the country, holding $24 \%$ of Brazil's eucalyptus plantations. This state also demonstrates socioeconomic relevance in this scenario due to the combination of small, medium and large productive systems (IBÁ, 2017). In 2017, for example, Minas Gerais accounted for $80 \%$ of the Brazilian charcoal production value, which generated an income of $\mathrm{R} \$$ 2.15 for the state, while Brazil generated a total of R\$ 2.57 million (IBGE, 2018).

In recent years several studies have aimed the improvement of wood quality for energy and the production systems (Costa et al., 2019). However, in Minas Gerais a significant part of charcoal production is still performed in rudimentary furnaces, such as rabo-quente, encosta and superficie (circular), which are systems with: reduced gravimetric yield, higher gas emissions and fewer carbonization control (CGEE, 2015). Though, replacing these rudimentary systems by more technological ones that require higher investment and that would increase carbonization expenses should inhibit their adoption by small and medium producers, who concentrate a significant part of the production (Vilela et al., 2014). In addition, the reduced investment capacity of small-scale producers is mainly due to the charcoal market price fluctuations, which makes unviable the investment in superior rectangular furnaces and machinery, in addition to their unawareness of financing options (Carneiro et al., 2013b). Therefore, studies should look for the development of systems that combine improvements in production yield, reduction of greenhouse gas emissions, and which are technically and economically viable and accessible to smaller producers.

The development of low-cost furnaces that are equipped with gas burning furnaces capable of reducing gas emissions are mechanisms that have been studied in the charcoal sector. A system considered a reference in both the constructive engineering and the carbonization control system is the fornosfornalha system, developed by the Federal University of Viçosa (Donato, 2017b). Unlike other traditional furnaces, which use subjective processes to control the carbonization (e.g., smoke color observation and the sensitivity of the furnace's wall external temperature by touch), fornos-fornalha presents defined carbonization curves, with temperature measurements by pyrometry, besides having a furnace to combust carbonization gases. It is also considered a system with reduced investment and operating expenses (Cardoso et al., 2010).

Some steel companies have developed productive systems designed in larger rectangular furnaces with gas combustion, which reduces the negative impact of pollutant emissions and with the possibility of even generating electricity in this process. Some of these larger systems can be found in studies (Leme et al., 2018; Vilela et al., 2014; Pereira et al., 2017). It should be noted, however, that many of these systems are unfeasible for small-scale producers, due to its higher investment, the increased need for machinery, skilled labor and technical knowledge.

Moreover, there are few studies in literature that address, comparatively, the economic viability of charcoal productive systems for small-scale producers. In order to understand if it is viable to implement a less polluting and better yielding system, this work developed an economic analysis of four systems used in Minas Gerais state: fornos-fornalha, rabo-quente, encosta and superficie.

\section{MATERIALS AND METHODS}

\subsection{Characterization of the productive systems}

Four productive systems were evaluated for an estimated monthly average production of 100 cubic meters of charcoal, which is close to the reality of small-scale producers in the state (Oliveira et al., 2014). Data were collected from charcoal producers in Lamim's region (MG) during 2018, and also in the literature. Each system has a distinct number of furnaces due to: their distinct volumetric capacity, determined in stereo firewood meter (st); the different time for a complete carbonization cycle, including charging, carbonization, cooling and unloading; and the yield of wood conversion into charcoal for each technology. The characterization of each system is described as follows:

Revista Árvore 2020;44:e4401 


\subsubsection{Fornos-fornalha system}

This production system was composed of four circular furnaces, constructed of masonry. Each furnace has six air controllers in its base for conducting carbonization. Its monitoring occurs through temperature measurements in metal cylinders, installed on furnaces' walls and domes, using a pyrometer (infrared thermometer). The gas burning furnace - present only in this system - is used to remove and incinerate carbonization gases, enabling environmental and performance gains. This furnace was built in a cylindrical shape, formed by a gas capture system via ducts and with valves for flow control, combustion chamber with grate, deflecting walls, primary air intake system and chimney (Donato, 2017b).

The main assumed parameters were: equipment life of six years; each furnace capacity of 13 st of firewood; complete carbonization cycle lasting seven days. Thus, each furnace performs four carbonizations per month, totaling 16 monthly carbonizations (for the system). Charcoal gravimetric yield was $32.50 \%$ and $4.00 \%$ for fines, as measured by Donato (2017b).

\subsubsection{Rabo-quente system}

This system was constituted of five traditional semi-spherical furnaces, built in masonry and clay. These furnaces have openings in their bases for air access (tatus, in Portuguese), allowing the partial firewood combustion. Distributed throughout the dome there are small openings called baianas, which serve as smoke exits and to smoke's color control in order to assess the carbonization evolution. These furnaces do not have chimneys and do not allow the inclusion of devices to reduce pollutant emissions (Colombo et al., 2006).

The main productive parameters were as follows: furnace life of two years; each furnace capacity of 13 st of firewood; carbonization cycle lasting seven days. Each furnace performs four carbonizations per month, being 20 carbonizations for the system/month. Charcoal gravimetric yield considered was $26.00 \%$ and $8.00 \%$ for fines (Oliveira et al., 2014).

\subsubsection{Encosta system}

This system was composed of six traditional furnaces used in mountainous regions of Minas Gerais, well-known among small producers. Encosta furnaces (also known as barranco furnaces) are made of domes built of solid bricks and clay, resting on the slope that works as a wall. Due to the thermal insulation provided by the slope, these furnaces require longer cooling time than the other models, lengthening the productive cycle and resulting in fewer carbonizations per furnace/month (CGEE, 2015).

The main assumed parameters were: furnace life of six years; each furnace capacity of 13 st of firewood; and carbonization cycle lasting ten days. Each furnace can perform three carbonizations per month, being 18 carbonizations for the system/month. Charcoal gravimetric yield was $30.00 \%$ and $8.00 \%$ for fines.

\subsubsection{Superfície system}

This system was constituted of eight surface furnaces entirely built of common solid bricks and clay - without a gas burning furnace. Although it is the same furnace model used in fornos-fornalha, for this system a smaller-capacity furnace of 7 st of firewood was used, which is more common in the evaluated region. With that, more furnaces were needed to reach the production of 100 cubic meters of charcoal/month.

The main assumed productive parameters were: furnace life of five years; each furnace capacity of 7 st of firewood; carbonization cycle lasting seven days. Each furnace can perform four carbonizations per month, corresponding to 32 carbonizations for the system/month. Charcoal gravimetric yield was $30.00 \%$ and $4.00 \%$ for fines (Brito, 2010).

The systems cash flow was elaborated for a 10year planning horizon, with furnace construction in year zero and further reconstructions at the end of the furnace life.

\subsection{Productive system's expenses}

Construction, operation and maintenance expenses were obtained from Lamim's local producers - Minas Gerais state (Table 1). The following assumptions were considered: i) construction expenses are incurred in year zero of each system and in the year in which the furnace life is completed; ii) since the system's construction period is reduced (from five to fifteen days), charcoal production was not affected by construction and reconstructions along the cash

Revista Árvore 2020;44:e4401 
Table 1 - Productive systems characterization and expenses.

Tabela 1 - Caracterização e despesas dos sistemas produtivos.

\begin{tabular}{|c|c|c|c|c|c|}
\hline Data & Unit & Fornos-fornalha & Rabo-quente & Encosta & Superficie \\
\hline \multicolumn{6}{|l|}{ Productive parameters } \\
\hline Number of furnaces & - & 4 & 5 & 6 & 8 \\
\hline Furnace life & years & 6.00 & 2.00 & 6.00 & 5.00 \\
\hline Furnace capacity & st & 13.00 & 13.00 & 13.00 & 7.00 \\
\hline Full carbonization/furnace & days & 7.00 & 7.00 & 10.00 & 7.00 \\
\hline Carbonizations/month & - & 16 & 20 & 18 & 32 \\
\hline Charcoal yield & $\%$ & $32.50 \%$ & $26.00 \%$ & $30.00 \%$ & $30.00 \%$ \\
\hline Fines yield & $\%$ & $4.00 \%$ & $8.00 \%$ & $8.00 \%$ & $4.00 \%$ \\
\hline \multicolumn{6}{|l|}{ Expenses } \\
\hline Construction expenses & $\mathrm{R} \$$ & $10,173.05$ & $10,050.00$ & $8,400.00$ & $12,116.00$ \\
\hline Furnaces & $\mathrm{R} \$$ & $4,858.00$ & $7,650.00$ & $6,000.00$ & $9,716.00$ \\
\hline Gas burning furnace & $\mathrm{R} \$$ & $2,915.05$ & - & - & - \\
\hline Labor expenses & $\mathrm{R} \$$ & $2,400.00$ & $2,400.00$ & $2,400.00$ & $2,400.00$ \\
\hline Operation and maintenance (annual) & $\mathrm{R} \$$ & $24,460.65$ & $24,454.50$ & $24,372.00$ & $24,557.80$ \\
\hline Management and maintenance & $\mathrm{R} \$$ & 508.65 & 502.5 & 420 & 605.8 \\
\hline Operational labor expenses & $\mathrm{R} \$$ & $23,952.00$ & $23,952.00$ & $23,952.00$ & $23,952.00$ \\
\hline \multicolumn{6}{|l|}{ Financing } \\
\hline Financing value & $\mathrm{R} \$$ & $97,533.05$ & $119,250.00$ & $106,680.00$ & $106,196.00$ \\
\hline System construction & $\mathrm{R} \$$ & $10,173.05$ & $10,050.00$ & $8,400.00$ & $12,116.00$ \\
\hline Working capital & $\mathrm{R} \$$ & $87,360.00$ & $109,200.00$ & $98,280.00$ & $94,080.00$ \\
\hline
\end{tabular}

Source: Own elaboration.

Fonte: Elaboração própria

flow; iii) construction labor expenses were equal for all systems; iv) annual operating and maintenance expenses were comprised of a management and maintenance expense of $5 \%$ of the construction value, as well as an operating labor cost of one worker, composed of a monthly national minimum wage of R\$ 998.00 (Brasil, 2019), multiplied by 12 months and added $100 \%$ of this amount, attributed to taxes and other labor expenses; (v) it was assumed that at the end of their useful life, the furnaces would be entirely replaced/reconstructed without the harnessing of bricks or any materials, making the expenditure equivalent to the full construction cost. The purpose of these assumptions is to avoid intrinsic oscillations in the processes and to be consistent with the reality of small producers in Minas Gerais, considering that complete reconstruction without use of the remaining material is common in the carbonization sites on small-scale producers.

The main economic parameters adopted for all systems were: discount rate (capital cost) of $10.00 \%$ per year, considered reasonable for bioenergy investment projects (Martelanc et al., 2010); linear depreciation rate of $10.00 \%$ p.a.; tax on profit of $34.00 \%$ (for charcoal sales in Minas Gerais, there is no tax on circulation of goods and services - known as ICMS in Portuguese); wood purchase price of R\$ $50.00 / \mathrm{m}^{3}$ and charcoal sale price of $\mathrm{R} \$ 600.00 /$ ton, which are average values practiced in the region at the time of data collection (2018).

A financing was also stipulated for each productive system, aiming to fund $100 \%$ of the system's construction value and the working capital needed to purchase wood in the first operational year. That is, the amount financed was the sum of the total construction expense (including labor for construction) with the monthly wood purchases value in the first year. Values and conditions were simulated with the National Bank of Economic and Social Development (BNDES, in Portuguese) credit line called BNDES Finame Renewable Energy, at a real interest rate of $4.5 \%$ per year for 6 years, grace period of 3 years, and monthly payment via Constant Amortization System. It is important to highlight that forest assets were not included in the valuation, only the purchase of wood from third parties.

An analysis of the impact of the charcoal fines sales on the financial indicators was performed. Fines are also known in the Brazilian forest market as

Revista Árvore 2020;44:e4401 
moinha. In this alternative scenario, it was considered the sale of fines every year at the price of R\$150.00/ ton. It is noteworthy that rabo-quente and encosta systems have higher fines gravimetric yield $(8.00 \%)$, and that these residues are usually discarded or used for incorporation into the soil to improve its properties. Therefore, the revenue of the fines sales is not so common in the productive reality of the small and medium producers of Minas Gerais.

\subsection{Discounted cash flow}

To assess the economic viability of each productive system, the discounted cash flow (DCF) method was used, in which is estimated the project value discounted at a rate that reflects the risk associated to the investment. In this methodology, the project value is measured by the amount of financial resources that will be generated in the future by the business, which is taken into present value to reflect the time and risk associated with the distribution (Martelanc et al., 2010). For this purpose, the free cash flow of each productive system was calculated, representing the cash flow generated after deduction of taxes, fixed investments and expected changes in net working capital (Damodaran, 2007).

Net Present Value (NPV), Modified Internal Rate of Return (MIRR) and Payback were the financial indicators used. NPV (Eq. 1) was used to determine the present value of future payments discounted at a given interest rate less the cost of the initial investment. The interest rate used was the capital cost (10\% p.a.). The system is considered economically viable when NPV is greater than zero (Rodrigues and Rozenfeld, 2015).

$$
N P V=\sum_{j=0}^{n} R j(1+i)^{-j}-\sum_{j=0}^{n} C j(1+i)^{-j}
$$

where: $i=$ interest rate; $c j=$ cost at the end of year $j ; R j=$ revenue at the end of year $j$; and, $\mathrm{n}=$ project duration in years.

MIRR (Eq. 2) is the Internal Rate of Return's (IRR) derivation and was developed to correct IRR limitations. MIRR assumes that the project's positive cash flows are reinvested at the project's capital cost, and that the initial costs are refunded at the company's financing cost. In a different way, the IRR assumes that the project's cash flows are reinvested in its own IRR. Therefore, MIRR is considered a rate that more accurately reflects the financial attractiveness of a project (Kierulff, 2008). The charcoal system is considered economically viable by this criteria if the MIRR estimated is higher than the discount rate adopted, which in the case of this analysis was $10.00 \%$ p.a.

$M I R R=\left(\frac{-N P V(\text { r rate, } \text { values }[\text { positives }]) x(1+\text { r rate })^{n}}{N P V(\text { rate, values }[\text { negatives }]) x(1+\text { frate })}\right)^{\frac{1}{n-1}}-1$

where: $r$ rate $=$ refunding rate $=$ capital cost; $f$ rate $=$ funding rate $=8.00 \%$ p.a.; and, $n=$ project duration in years.

Payback indicator is used to determine how long an investment takes to be repaid. It is calculated by accumulating the financials inputs and outputs until the period in which a negative value has been transitioned to a positive value, that is, the moment when all that has been invested is recovered (Rodrigues and Rozenfeld, 2015).

NPV sensitivity analyzes of each system were also performed (at a rate of $10.00 \%$ p.a.) to evaluate how the indicators of charcoal gravimetric yield (CGY) and charcoal selling price affect the systems viability. CGY varied by eight percentage points up and down and the selling price from $\mathrm{R} \$ 400.00$ to $\mathrm{R} \$ 800.00$ / ton. The objective of this analysis was to evaluate the NPV of each system in different production scenarios (CGY) and market situations (charcoal price).

\subsection{Expenses indicators - capex and opex}

Two expenses indicators were analyzed: capital expenditures (capex) and operating expenditures (opex), considered two common indicators in energy projects (Pinto Junior et al., 2007). Capex is the sum of all expenses required for a system goes into production, consisting of the total construction expenses: machinery, equipment, construction work and labor over the planning horizon. This sum was divided by the total amount of charcoal produced in the 10-years of the project (in tons). Thus, the indicator capex/ton of charcoal was obtained. Opex can be calculated on an annual basis and is the sum of the operating expenses of a project in a year, consisting 
of production expenses, general and administrative expenses and operating labor. This sum was divided by the amount of charcoal produced in one year to obtain the indicator opex/ton of charcoal produced in one year. These indicators' applicability occurs mainly when compared to other projects of similar production level, dividing the calculated monetary value by the amount produced (Martelanc et al., 2010).

\subsection{Carbonization gravimetric yield}

The carbonization gravimetric yield was calculated using the charcoal gravimetric yield indicator (CGY), which is commonly used in the charcoal industry and in the literature. The charcoal (Eq. 3) and fines (Eq. 4) masses were calculated by the following equations, according to Carneiro et al. (2013b):

$$
C G Y=100 \times \frac{M_{c}}{M_{w}}
$$

where: $\mathrm{CGY}=$ charcoal gravimetric yield (\%); $\mathrm{M}_{\mathrm{c}}=$ mass of charcoal $(\mathrm{kg})$; and, $\mathrm{M}_{\mathrm{w}}=$ mass of dry $\operatorname{wood}(\mathrm{kg})$.

$$
F G Y=100 \times \frac{M_{f}}{M_{d w}}
$$

where: $\mathrm{FGY}=$ fines gravimetric yield $(\%) ; \mathrm{M}_{\mathrm{f}}=$ mass of fines $(\mathrm{kg})$; and, $\mathrm{M}_{\mathrm{w}}=$ mass of dry wood $(\mathrm{kg})$.

A conversion factor of 0.7 was adopted to convert firewood stereo into cubic meter. The other assumptions were: average density of wood to be carbonized equal to $480.00 \mathrm{~kg} / \mathrm{m}^{3}$ and average density of charcoal produced equal to $220.00 \mathrm{~kg} / \mathrm{m}^{3}$, which are values usually observed for the wood used in charcoal production (Carneiro and Oliveira, 2013a).

\section{RESULTS}

By the NPV criteria, it was observed that all systems were economically viable. Fornos-fornalha system was the most viable, with higher NPV (R\$ 116.59 thousand), encosta and superficie systems with intermediate values ( $\mathrm{R} \$ 95.31$ thousand and R\$ 79.78 thousand, respectively) and rabo-quente system with the lowest NPV (R\$ 3.66 thousand), although still above zero (Table 2). By the MIRR criteria, fornos-fornalha again achieved the highest viability, with MIRR of $45.2 \%$, greater than the $10 \%$ discount rate. Encosta and superficie systems obtained MIRR of $32.0 \%$ and $26.7 \%$, respectively. On the other hand, rabo-quente system achieved MIRR just below the discount rate $(9.8 \%)$, which makes it unviable, even though with a value very close to the rate (Table 2). For Payback criteria, fornos-fornalha, encosta and

Table 2 - Economic indicators results and NPV sensibility analysis at different discount rates.

\begin{tabular}{|c|c|c|c|c|c|}
\hline Indicators & Unit & Fornos-fornalha & Rabo-quente & Encosta & Superficie \\
\hline NPV (10.0\%) & $\mathrm{R} \$ \mathrm{k}$ & 116.59 & 3.66 & 95.31 & 79.78 \\
\hline MIRR & $\%$ & $45.2 \%$ & $9.8 \%$ & $32.0 \%$ & $26.7 \%$ \\
\hline Payback & years & 1 & 6 & 1 & 1 \\
\hline \multicolumn{6}{|l|}{ NPV sensitivity } \\
\hline NPV $(4.0 \%)$ & $\mathrm{R} \$ \mathrm{k}$ & 163.78 & 7.37 & 134.27 & 112.91 \\
\hline NPV $(6.0 \%)$ & $\mathrm{R} \$ \mathrm{k}$ & 145.31 & 5.62 & 118.96 & 99.84 \\
\hline NPV $(8.0 \%)$ & $\mathrm{R} \$ \mathrm{k}$ & 129.76 & 4.43 & 106.13 & 88.93 \\
\hline NPV (10.0\%) & $\mathrm{R} \$ \mathrm{k}$ & 116.59 & 3.66 & 95.31 & 79.78 \\
\hline NPV (12.0\%) & $\mathrm{R} \$ \mathrm{k}$ & 105.37 & 3.19 & 86.12 & 72.04 \\
\hline NPV $(14.0 \%)$ & $\mathrm{R} \$ \mathrm{k}$ & 95.74 & 2.93 & 78.27 & 65.46 \\
\hline NPV (16.0\%) & $\mathrm{R} \$ \mathrm{k}$ & 87.43 & 2.83 & 71.52 & 59.82 \\
\hline \multicolumn{6}{|c|}{ Scenario with fines } \\
\hline NPV (10.0\%) & $\mathrm{R} \$ \mathrm{k}$ & 135.15 & 50.04 & 137.05 & 99.75 \\
\hline MIRR & $\%$ & $56.0 \%$ & $18.8 \%$ & $55.6 \%$ & $32.4 \%$ \\
\hline Payback & years & 1 & 2 & 1 & 1 \\
\hline \multicolumn{6}{|c|}{ Expenditures indicators } \\
\hline Capex & $\mathrm{R} \$ /$ ton & 7.5 & 18.4 & 5.9 & 8.9 \\
\hline Opex & $\mathrm{R} \$ /$ ton & 410.3 & 490.4 & 433.3 & 437.9 \\
\hline
\end{tabular}

Tabela 2 - Resultado dos indicadores econômicos e sensibilidade do VPL diante de diferentes taxas de desconto.

Source: Work results; $\mathrm{k}=$ thousand.

Fonte: Resultados do trabalho. $k=$ mil.

Revista Árvore 2020;44:e4401 
superficie systems were able to pay off the investment with just one year of production. And rabo-quente system needed six years (Table 2).

When varying the discount rate from $4 \%$ to 16\%, fornos-fornalha, encosta and superficie systems obtained higher NPV values even under the impact of an elevated discount rate (16\% p.a.). Rabo-quente system did not present negative NPV values, although it remained well below the others (Table 2). The impact of the fines revenue on financial indicators showed that rabo-quente and encosta systems were significantly favored by this new revenue. Rabo-quente's NPV was R\$ 50.04 thousand, MIRR 18.8\% (above the discount rate) and Payback was only two years. Encosta system with this new revenue presented the highest NPV (R\$ 137.05 thousand), as well as increased MIRR (55.6\%) and Payback of one year (Table 2).

For the expenditure indicators (Table 2), encosta (R\$ 5.9 /ton) and fornos-fornalha (R\$ 7.5 /ton) were the systems with lower capex. The most expensive systems were rabo-quente (R\$ 18.4 /ton) and superficie (R\$ 8.9 /ton). For opex, fornos-fornalha obtained the lowest operating expenses (R\$ 410.3/ ton), while the most expensive was rabo-quente (R\$ 490.4 /ton).

In relation to charcoal production indicators, the systems presented very similar annual production, considering that the initial assumption for sizing the furnaces number was the production of 100 cubic meters of charcoal per month. However, the firewood consumption was higher in lower CGY systems: raboquente, encosta and superficie, respectively. Fornosfornalha consumed lesser wood due to its higher charcoal yield, which influenced its lower expenditure of firewood - the main input for charcoal production (Table 3). In the free cash flow analysis, all productive systems had negative flows only in the years in which debt is repaid (years 4, 5 and 6). In these years there were reconstructions in fornos-fornalha (year 6), rabo-quente (years 4 and 6), encosta (year 6) and superficie (year 5). In other years, expenditures and reconstructions impact did not generate negative cash flow (Table 3).

Regarding the NPV sensitivity analysis, for fornosfornalha if the charcoal sales price remains constant, only a CGY of $24.5 \%$ could bring the NPV to negative values, making the project unviable. On the other hand, keeping the CGY constant at $32.5 \%$, only a reduced charcoal price of $\mathrm{R} \$ 450.00 /$ ton would make the project unviable (Table 4). For rabo-quente system, maintaining the charcoal sales price of the base case scenario, the first reduction in CGY to $24.0 \%$ would lead to economic unfeasibility with negative NPV value. Similarly, keeping the CGY of the baseline scenario, the first reduction in the selling price ( $\mathrm{R} \$ 550.00 /$ ton) would make the rabo-quente system unviable (Table 4).

Table 3 - Firewood consumption, charcoal production and free cash flow of the productive systems.

Tabela 3 - Consumo de lenha, produção de carvão vegetal e fluxo de caixa livre dos sistemas produtivos.

\begin{tabular}{|c|c|c|c|c|c|c|c|c|c|c|c|}
\hline Data/year & 0 & 1 & 2 & 3 & 4 & 5 & 6 & 7 & 8 & 9 & 10 \\
\hline \multicolumn{12}{|l|}{ Fornos-fornalha(ton) } \\
\hline Firewood consumption & 0.0 & 838.7 & 838.7 & 838.7 & 838.7 & 838.7 & 838.7 & 838.7 & 838.7 & 838.7 & 838.7 \\
\hline Charcoal production & 0.0 & 272.6 & 272.6 & 272.6 & 272.6 & 272.6 & 272.6 & 272.6 & 272.6 & 272.6 & 272.6 \\
\hline \multicolumn{12}{|l|}{$\overline{\text { Rabo-quente(ton) }}$} \\
\hline Firewood consumption & 0.0 & 1048.3 & 1048.3 & 1048.3 & 1048.3 & 1048.3 & 1048.3 & 1048.3 & 1048.3 & 1048.3 & 1048.3 \\
\hline Charcoal production & 0.0 & 272.6 & 272.6 & 272.6 & 272.6 & 272.6 & 272.6 & 272.6 & 272.6 & 272.6 & 272.6 \\
\hline \multicolumn{12}{|l|}{$\overline{\text { Encosta(ton) }}$} \\
\hline Firewood consumption & 0.0 & 943.5 & 943.5 & 943.5 & 943.5 & 943.5 & 943.5 & 943.5 & 943.5 & 943.5 & 943.5 \\
\hline Charcoal production & 0.0 & 283.0 & 283.0 & 283.0 & 283.0 & 283.0 & 283.0 & 283.0 & 283.0 & 283.0 & 283.0 \\
\hline \multicolumn{12}{|l|}{ Superficie(ton) } \\
\hline Firewood consun & 0.0 & 903.2 & 903.2 & 903.2 & 903.2 & 903.2 & 903.2 & 903.2 & 903.2 & 903.2 & 903.2 \\
\hline Charcoal production & 0.0 & 271.0 & 271.0 & 271.0 & 271.0 & 271.0 & 271.0 & 271.0 & 271.0 & 271.0 & 271.0 \\
\hline \multicolumn{12}{|l|}{$\overline{\text { Free cash flow (R\$ k) }}$} \\
\hline Fornos-fornalha & 0.00 & 30.57 & 30.57 & 30.57 & -1.46 & -0.98 & -10.67 & 33.46 & 33.46 & 33.46 & 33.46 \\
\hline Rabo-quente & 0.00 & 15.52 & 5.47 & 15.52 & -33.69 & -23.05 & -32.51 & 19.06 & 9.01 & 19.06 & 19.06 \\
\hline Encosta & 0.00 & 27.41 & 27.41 & 27.41 & -7.62 & -7.09 & -14.96 & 30.58 & 30.58 & 30.58 & 30.58 \\
\hline Superficie & 0.00 & 25.04 & 25.04 & 25.04 & -9.83 & -21.42 & -8.78 & 28.20 & 28.20 & 28.20 & 28.20 \\
\hline
\end{tabular}

Source: Work results. $\mathrm{k}=$ thousand.

Fonte: Resultados do trabalho. $k=$ mil. 
Table 4 - NPV sensitivity analysis of fornos-fornalha and rabo-quente systems for variations in charcoal yield and price.

Tabela 4 - Sensibilidade do NPV dos sistemas fornos-fornalha e rabo-quente diante de variações no rendimento e preço do carvão vegetal.

\begin{tabular}{|c|c|c|c|c|c|c|c|c|c|c|}
\hline \multicolumn{11}{|c|}{ Fornos-fornalha } \\
\hline \multirow{2}{*}{\multicolumn{2}{|c|}{ NPV (R\$ k) }} & \multicolumn{8}{|c|}{ CGY } & \\
\hline & & 0.245 & 0.265 & 0.285 & 0.305 & 0.325 & 0.345 & 0.365 & 0.385 & 0.405 \\
\hline \multirow{9}{*}{$\begin{array}{l}\text { Charcoal price } \\
\text { (R\$/ton) }\end{array}$} & 400.00 & $(183.32)$ & (158.59) & (133.85) & $(109.11)$ & $(84.38)$ & $(59.64)$ & (34.91) & (10.17) & 14.56 \\
\hline & 450.00 & (145.44) & (117.62) & (89.79) & $(61.96)$ & (34.14) & $(6.31)$ & 21.52 & 49.35 & 77.17 \\
\hline & 500.00 & (107.57) & $(76.65)$ & $(45.73)$ & (14.81) & 16.11 & 47.03 & 77.95 & 108.86 & 139.78 \\
\hline & 550.00 & $(69.69)$ & $(35.68)$ & (1.67) & 32.34 & 66.35 & 100.36 & 134.37 & 168.38 & 202.39 \\
\hline & 600.00 & $(31.82)$ & 5.29 & 42.39 & 79.49 & 116.59 & 153.70 & 190.80 & 227.90 & 265.01 \\
\hline & 650.00 & 6.06 & 46.25 & 86.45 & 126.64 & 166.84 & 207.03 & 247.23 & 287.42 & 327.62 \\
\hline & 700.00 & 43.93 & 87.22 & 130.51 & 173.79 & 217.08 & 260.37 & 303.65 & 346.94 & 390.23 \\
\hline & 750.00 & 81.81 & 128.19 & 174.57 & 220.95 & 267.32 & 313.70 & 360.08 & 406.46 & 452.84 \\
\hline & 800.00 & 119.69 & 169.16 & 218.63 & 268.10 & 317.57 & 367.04 & 416.51 & 465.98 & 515.45 \\
\hline \multicolumn{11}{|c|}{ Rabo-quente } \\
\hline \multirow{2}{*}{\multicolumn{2}{|c|}{$\overline{\mathrm{NPV}(\mathrm{R} \$ \mathrm{k})}$}} & \multicolumn{8}{|c|}{ CGY } & \\
\hline & & 0.180 & 0.200 & 0.220 & 0.240 & 0.260 & 0.280 & 0.300 & 0.320 & 0.340 \\
\hline \multirow{9}{*}{$\begin{array}{l}\text { Charcoal price } \\
\text { (R\$/ton) }\end{array}$} & 400.00 & (320.99) & (290.07) & $(259.15)$ & $(228.23)$ & (197.32) & (166.40) & (135.48) & $(104.56)$ & (73.64) \\
\hline & 450.00 & $(286.21)$ & $(251.42)$ & (216.64) & (181.86) & (147.07) & (112.29) & $(77.50)$ & $(42.72)$ & (7.94) \\
\hline & 500.00 & $(251.42)$ & (212.78) & (174.13) & (135.48) & $(96.83)$ & $(58.18)$ & (19.53) & 19.12 & 57.77 \\
\hline & 550.00 & (216.64) & (174.13) & (131.61) & $(89.10)$ & (46.59) & $(4.07)$ & 38.44 & 80.96 & 123.47 \\
\hline & 600.00 & (181.86) & (135.48) & $(89.10)$ & $(42.72)$ & 3.66 & 50.04 & 96.42 & 142.79 & 189.17 \\
\hline & 650.00 & (147.07) & $(96.83)$ & (46.59) & 3.66 & 53.90 & 104.15 & 154.39 & 204.63 & 254.88 \\
\hline & 700.00 & (112.29) & $(58.18)$ & $(4.07)$ & 50.04 & 104.15 & 158.25 & 212.36 & 266.47 & 320.58 \\
\hline & 750.00 & $(77.50)$ & (19.53) & 38.44 & 96.42 & 154.39 & 212.36 & 270.34 & 328.31 & 386.28 \\
\hline & 800.00 & $(42.72)$ & 19.12 & 80.96 & 142.79 & 204.63 & 266.47 & 328.31 & 390.15 & 451.98 \\
\hline
\end{tabular}

Source: Work results $\mathrm{k}=$ thousand.

Fonte: Resultados do trabalho. $k=$ mil.

Encosta system would need a CGY of $24.0 \%$ to turn it unviable (at base case charcoal selling price), but if the charcoal price falls to R\$500.00/ton, keeping the CGY constant, this system would be unviable (Table 5). For superficie system, if the CGY is reduced to $26.0 \%$, the system would become NPV negative, making it unfeasible at constant selling price. On the other hand, keeping the CGY of the baseline scenario, a reduction in the charcoal selling price to $\mathrm{R} \$ 500.00$ /ton would turn this system unviable (Table 5).

\section{DISCUSSION}

The analyzed charcoal productive systems, although with different furnaces number, have approximately the same production capacity of 100 cubic meters of charcoal/month. However, the difference in systems charcoal gravimetric yields signified that lower-yield systems required more firewood to produce the same amount of charcoal. In this way, traditional furnaces obtained higher operating expenses (opex) than fornos-fornalha system (Table 2).
Rabo-quente, encosta and superfície systems consumed 1,048, 943 and 903 tons of firewood/year, respectively, to produce similar amount of charcoal of fornos-fornalha. This system, in turn, consumed 839 tons/year (Table 3). The furnaces life was also different, which obligated shorter-life systems (such as rabo-quente) to realize earlier reinvestments, generating higher expenses and affecting its cash flow. For this reason, rabo-quente obtained the highest capital expenditures (capex), significantly above the others (Table 2).

Rabo-quente system had the lowest free cash flow over several years (Table 3 ). And in debt repayment years its flow deteriorated further, which reduced its viability. In addition, the increased need to purchase firewood in the first year for rabo-quente, encosta and superficie systems has raised their financing cost and thus the amount to be paid by them.

When ignoring the fines revenue, fornosfornalha system obtained the best financial indicators, demonstrating that the revenue generated exclusively

Revista Árvore 2020;44:e4401 
Table 5 - NPV sensitivity analysis of encosta and superficie systems for variations in charcoal yield and price.

Tabela 5 - Sensibilidade do NPV dos sistemas encosta e superfície diante de variações no rendimento e preço do carvão vegetal.

\begin{tabular}{|c|c|c|c|c|c|c|c|c|c|c|}
\hline \multicolumn{11}{|c|}{ Encosta } \\
\hline \multirow[t]{5}{*}{ NPV (R\$ k) } & & \multicolumn{9}{|c|}{ CGY } \\
\hline & & 0.220 & 0.240 & 0.260 & 0.280 & 0.300 & 0.320 & 0.340 & 0.360 & 0.380 \\
\hline & 400.00 & $(224.70)$ & (196.88) & (169.05) & $(141.22)$ & (113.39) & (85.57) & $(57.74)$ & (29.91) & (2.09) \\
\hline & 450.00 & (186.44) & (155.14) & $(123.83)$ & $(92.52)$ & $(61.22)$ & (29.91) & 1.39 & 32.70 & 64.00 \\
\hline & 500.00 & (148.18) & (113.39) & $(78.61)$ & $(43.83)$ & (9.04) & 25.74 & 60.53 & 95.31 & 130.09 \\
\hline \multirow{6}{*}{$\begin{array}{l}\text { Charcoal price } \\
\text { (R\$/ton) }\end{array}$} & 550.00 & $(109.92)$ & $(71.65)$ & (33.39) & 4.87 & 43.13 & 81.40 & 119.66 & 157.92 & 196.18 \\
\hline & 600.00 & $(71.65)$ & (29.91) & 11.83 & 53.57 & 95.31 & 137.05 & 178.79 & 220.53 & 262.27 \\
\hline & 650.00 & (33.39) & 11.83 & 57.05 & 102.27 & 147.49 & 192.70 & 237.92 & 283.14 & 328.36 \\
\hline & 700.00 & 4.87 & 53.57 & 102.27 & 150.96 & 199.66 & 248.36 & 297.06 & 345.75 & 394.45 \\
\hline & 750.00 & 43.13 & 95.31 & 147.49 & 199.66 & 251.84 & 304.01 & 356.19 & 408.36 & 460.54 \\
\hline & 800.00 & 81.40 & 137.05 & 192.70 & 248.36 & 304.01 & 359.67 & 415.32 & 470.98 & 526.63 \\
\hline \multicolumn{11}{|c|}{ Superficie } \\
\hline \multirow[t]{5}{*}{ NPV (R\$ k) } & & \multicolumn{9}{|c|}{ CGY } \\
\hline & & 0.220 & 0.240 & 0.260 & 0.280 & 0.300 & 0.320 & 0.340 & 0.360 & 0.380 \\
\hline & 400.00 & $(226.56)$ & (199.92) & (173.28) & $(146.65)$ & $(120.01)$ & (93.37) & $(66.73)$ & (40.09) & (13.46) \\
\hline & 450.00 & (189.93) & (159.97) & $(130.00)$ & $(100.03)$ & $(70.06)$ & (40.09) & (10.13) & 19.84 & 49.81 \\
\hline & 500.00 & $(153.31)$ & $(120.01)$ & $(86.71)$ & $(53.41)$ & $(20.12)$ & 13.18 & 46.48 & 79.78 & 113.07 \\
\hline Charcoal price & 550.00 & (116.68) & $(80.05)$ & $(43.42)$ & $(6.80)$ & 29.83 & 66.46 & 103.08 & 139.71 & 176.34 \\
\hline \multirow[t]{5}{*}{ (R\$/ton) } & 600.00 & $(80.05)$ & (40.09) & $(0.14)$ & 39.82 & 79.78 & 119.73 & 159.69 & 199.65 & 239.60 \\
\hline & 650.00 & $(43.42)$ & $(0.14)$ & 43.15 & 86.44 & 129.72 & 173.01 & 216.30 & 259.58 & 302.87 \\
\hline & 700.00 & $(6.80)$ & 39.82 & 86.44 & 133.05 & 179.67 & 226.29 & 272.90 & 319.52 & 366.13 \\
\hline & 750.00 & 29.83 & 79.78 & 129.72 & 179.67 & 229.61 & 279.56 & 329.51 & 379.45 & 429.40 \\
\hline & 800.00 & 66.46 & 119.73 & 173.01 & 226.29 & 279.56 & 332.84 & 386.11 & 439.39 & 492.66 \\
\hline
\end{tabular}

by the charcoal sale was sufficient to bring return to the producer. With this revenue, at the sale price of $\mathrm{R} \$$ 600.00 /ton, it was possible to cover all expenses within 10 years: construction, operation and maintenance, financial, depreciation, taxes and debt amortization, besides generating economic return to investor/producer. Again, its reduced firewood consumption greatly contributed to improve the cash flow and the system viability, and also generated lower operating expenses.

Thus, it can be said that fornos-fornalha system is a viable option for small and medium charcoal producers. With this charcoal yield of $32.5 \%$, greater economic viability was demonstrated when compared to traditional furnaces used in Minas Gerais, still presenting technical differentials, such as pyrometry to improve gravimetric yield and reduced emissions of pollutant gases - harmful to man and environment. Its financial robustness was also fundamental in the sensitivity analysis for charcoal selling price fluctuations. According to the sensitivity analysis (Tables 4 and 5), fornos-fornalha system was the only one that, keeping its CGY constant, would be viable at the charcoal selling price of R\$ 500.00 /ton, i.e., the other systems, considered traditional, are more susceptible to market fluctuations.

Regarding variations in fornos-fornalha gravimetric yield, Oliveira et al. (2013) observed for a similar system, with 12 stereos capacity per furnace, a charcoal yield of $35.61 \%$ and fines of $8.85 \%$. Cardoso et al. (2010) obtained an average CGY of $28.70 \%$ and $4 \%$ of residues in a reduced rectangular furnace coupled to a gas burning furnace, called MF1-UFV, with 8 st capacity. In the current work, at charcoal selling price of $\mathrm{R} \$ 600.00$ /ton, fornos-fornalha system was still economically viable with CGY of $26.5 \%$ (Table 4 ), that is, below the yields found in literature for different carbonization systems with gas burning furnaces.

Oliveira et al. (2013) also performed an economic analysis of a fornos-fornalha system, considering different scenarios of wood expenses and production capacity of 131 cubic meters of charcoal/month. This system was compared with the rabo-quente furnace, and the results also demonstrated fornos-fornalha greater viability and reduced viability of rabo-quente, endorsing the perceptions of the present work. For 
industrial scale production, for example, Donato et al. (2017a) obtained the highest economic indicators in greater volume furnaces and in higher production scenarios, which demonstrates the importance of economies of scale and better utilization of the internal capacity of these systems.

Finally, it is important to emphasize that the use of systems such as fornos-fornalha, with reduced wood consumption, minimal generation of polluting gases, and which can be inserted into the productive reality of small and medium producers, is a significant tool for sustainable development from a socioeconomic and environmental point of view. This technology can still be exported to countries that use archaic productive techniques, as pointed out in some studies, such as Feuerbacher et al. (2016) and Alfaro and Jones (2018), who demonstrated the importance of charcoal production for small-scale producers in some African and Asian countries. In this way, income generation, employment, reduction of native forests pressure and awareness of the use of a bioenergy can be expanded.

\section{CONCLUSION}

All systems were economically viable by the NPV criteria; only rabo-quente was not viable by the MIRR criteria. Fornos-fornalha system presented the best results for the evaluated economic indicators, with higher net revenue and free cash flow generation, and lower operational expenses. This system was also less sensitive to fluctuations in the charcoal selling price and to the reduction in charcoal gravimetric yield. Its greater insertion can be interesting in the productive reality of small and medium producers.

The possibility of selling charcoal fines has resulted in the improvement of economic indicators, especially for traditional systems: rabo-quente and encosta.

For further works, in addition to the potential for reducing greenhouse gas emissions, points related to the quality of wood for energy should be noted, such as basic density, heating value, moisture content, chemical composition, etc.

\section{ACKNOWLEDGMENTS}

To the Coordination for the Improvement of Higher Education Personnel (CAPES) and to the
Project of Sustainable Steel from the United Nations Development Program.

\section{REFERENCES}

Alfaro JF, Jones B. Social and environmental impacts of charcoal production in Liberia: evidence from the field. Energy for Sustainable Development. 2018;47:124-132. doi:10.1016/j.esd.2018.09.004

Brasil. Decreto n. 9.661, de $1^{\circ}$ de jan. de 2019. Dispõe sobre o valor do salário mínimo e a sua política de valorização de longo prazo. Disponível em: http:/www.planalto.gov.br/ccivil_03/_ato20192022/2019/decreto/D9661.htm

Brito JO. Desafios e perspectivas da produção e comercialização do carvão vegetal. In: II Fórum Nacional sobre Carvão Vegetal. Anais - Sete Lagoas (MG); 2010.

Cardoso MT, Damásio RAP, Carneiro ACO, Jacovine LAG, Vital BR, Barcelos DC. Construção de um sistema de queima de gases da carbonização para redução da emissão de poluentes. Cerne. 2010;16(Supll.):115-124.

Carneiro ACO, Oliveira AC. Produção sustentável de carvão vegetal. 1'a . ed. Viçosa, MG: UFV; 2013a. p. 39.

Carneiro ACO, Vital BR, Oliveira AC, Pereira BLC. Pirólise lenta da madeira para produção de carvão vegetal. In: F Santos, Colodete J, Queiroz JH, editores. Bioenergia e Biorrefinaria: cana de açúcar e espécies florestais. $1^{\mathrm{a}}$. ed. Viçosa, MG: Os Editores; 2013b. p.429-457.

Centro de Gestão e Estudos Estratégicos - CGEE. Modernização da produção de carvão vegetal no Brasil: subsídios para revisão do Plano Siderurgia; 2015.

Colombo SFO, Hatakeyama K, Pilatti LA. O custo de produção como fator determinante do futuro da produção artesanal de carvão vegetal no brasil. In: XIII Simpósio de Engenharia de Produção. Bauru (SP). Anais. 2006.

Costa ACPR, Ramalho FMG, Costa LR, Trugilho PF, Hein PRG. Classification of commercial charcoal for domestic use by near infrared spectroscopy. Biomass and Bioenergy. 2019;127:105280. doi: 10.1016/j. biombioe.2019.105280 
Damodaran A. Avaliação de Empresas. 2. ed. São Paulo: Pearson Universidades; 2007.

Donato DB, Magalhães MA, Carneiro ACO, Silva CMS, Canal WD, Silva ML. Viabilidade econômica de diferentes sistemas de produção de carvão vegetal em escala industrial. Ciência da Madeira (Brazilian Journal of Wood Science). 2017a;8(3):143-149. doi:10.12953/2177-6830/rcm. v8n3p143-149

Donato DB. Desenvolvimento e avaliação de fornalha para combustão dos gases da carbonização da madeira. [tese]. Viçosa, MG. Universidade Federal de Viçosa; $2017 \mathrm{~b}$.

Empresa de Pesquisa Energética - EPE. Balanço Energético Nacional. Relatório síntese ano base 2018 [online]. Rio de Janeiro: EPE; 2018. Available from: https://ben.epe.gov.br/benrelatoriosintese.aspx

Feuerbacher A, Siebold M, Chhetri A, Lippert C, Sander K. Increasing forest utilization within Bhutan's forest conservation framework: the economic benefits of charcoal production. Forest Policy and Economics. 2016;73:99-111. doi:10.1016/j.forpol.2016.08.007

Indústria Brasileira de Árvores - IBÁ. Relatório Anual. v. 1. 2017. 100 p.

Instituto Brasileiro de Geografia e Estatística - IBGE. Produção da Extração Vegetal e da Silvicultura PEVS; 2018. p. 48.

Kierulff H. MIRR: A better measure. Business Horizons. 2008;51(4):321-329. doi: https://doi. org/10.1016/j.bushor.2008.02.005

Leme MMV, Venturini OJ, Lora EES, Rocha
MH, Luz FC, Almeida W, et al. Electricity generation from pyrolysis gas produced in charcoal manufacture: Technical and economic analysis. J Clean Prod. 2018;194:219-42. doi: https://doi. org/10.1016/j.jclepro.2018.05.101

Martelanc R, Pasin R, Cavalcante F. Avaliação de Empresas: Um Guia para Fusões \& Aquisições e Gestão de Valor. Pearson/Financial Times; 2010.

Oliveira AC, Salles TT, Pereira BLC, Carneiro ACO, Braga CS, Santos RC. Viabilidade econômica da produção de carvão vegetal em dois sistemas produtivos. Floresta. 2014; 44(1):143-152.

Pereira EG, Martins MA, Pecenkab R, Carneiro ACO. Pyrolysis gases burners: Sustainability for integrated production of charcoal, heat and electricity. Renewable and Sustainable Energy Reviews. 2017;75:592-600. doi: https://doi. org/10.1016/j.rser.2016.11.028

Pinto Junior HQ. Economia da Energia: fundamentos econômicos, evolução histórica e organização industrial. 5. ed. Rio de Janeiro: Elsevier; 2007.

Rodrigues KFC, Rozenfeld H. Análise de Viabilidade Econômica. EI2, Grupo Engenharia Integrada e Engenharia de Integração. Divulgado em março, 2015. Portal de Conhecimentos: Disponível em: $<$ http://www.portaldeconhecimentos.org.br/index. php/por/content/view/full/16949>. Acesso em: 20 de fevereiro 2019.

Vilela AO, Lora ES, Quintero QR, Vicintin RA, Souza TPS. A new technology for the combined production of charcoal and electricity through cogeneration. Biomass and Bioenergy. 2014;69:222-240. doi: https://doi.org/10.1016/j. biombioe.2014.06.019 